University of Nebraska - Lincoln

DigitalCommons@University of Nebraska - Lincoln

USDA Wildlife Services - Staff Publications

U.S. Department of Agriculture: Animal and

Plant Health Inspection Service

2009

Feasibility of Infectious Prion Digestion Using Mild Conditions and Commercial Subtilisin

John L. Pilona

USDA/APHIS/WS National Wildlife Research Center

Paul B. Nash

USDA-APHIS-Wildlife Services

Terry Arver

Prion Tech, 15 Tyrell, Menomonie, WI 54715, United States

Don Hoglund

Prion Tech, PO Box 37780, Raleigh, NC 27592, United States

Kurt C. VerCauteren

USDA-APHIS-Wildlife Services, kurt.c.vercauteren@usda.gov

Follow this and additional works at: https://digitalcommons.unl.edu/icwdm_usdanwrc

Part of the Environmental Sciences Commons

Pilona, John L.; Nash, Paul B.; Arver, Terry; Hoglund, Don; and VerCauteren, Kurt C., "Feasibility of Infectious Prion Digestion Using Mild Conditions and Commercial Subtilisin" (2009). USDA Wildlife Services - Staff Publications. 950.

https://digitalcommons.unl.edu/icwdm_usdanwrc/950

This Article is brought to you for free and open access by the U.S. Department of Agriculture: Animal and Plant Health Inspection Service at DigitalCommons@University of Nebraska - Lincoln. It has been accepted for inclusion in USDA Wildlife Services - Staff Publications by an authorized administrator of DigitalCommons@University of Nebraska - Lincoln. 


\title{
Feasibility of infectious prion digestion using mild conditions and commercial subtilisin
}

\author{
John L. Pilon ${ }^{\mathrm{a}, \mathrm{d}, 1}$, Paul B. Nash ${ }^{\mathrm{a}, 1}$, Terry Arver $^{\mathrm{b}}$, Don Hoglund ${ }^{\mathrm{c}}$, Kurt C. VerCauteren ${ }^{\mathrm{a}, *}$ \\ a National Wildlife Research Center, 4101 Laporte Ave., Fort Collins, CO 80521, United States \\ b Prion Tech, 15 Tyrell, Menomonie, WI 54715, United States \\ c Prion Tech, PO Box 37780, Raleigh, NC 27592, United States \\ ${ }^{\mathrm{d}}$ Tolmar Inc., 701 Centre Avenue, Fort Collins, CO 80526, United States
}

Article history:

Received 7 December 2007

Received in revised form 22 January 2009

Accepted 28 April 2009

Available online 23 May 2009

\section{Keywords:}

Prion

Decontamination

Mouse-adapted scrapie

Subtilisin

Chronic wasting disease

\begin{abstract}
A B S T R A C T
Two serine protease enzymes, subtilisin 309 and subtilisin 309-v, were used to digest brain homogenates containing high levels of prion infectivity using mildly alkaline conditions to investigate prion decontamination methods. To establish that PrPres infectivity was eliminated, we utilized the Rocky Mountain Laboratory (RML) mouse-adapted scrapie model system for bioassay. Only one digestion condition (subtilisin 309 at $138 \mathrm{mAU} / \mathrm{ml}, 55^{\circ} \mathrm{C}$ and $14 \mathrm{~h}$ digestion time $\mathrm{pH}$ 7.9) was considered to be highly relevant statistically $(P<0.001)$ compared to control, with $52 \%$ of challenged mice surviving until the end of the study period. In contrast, treatment of PrPres by autoclaving at $134{ }^{\circ} \mathrm{C}$ or treatment with hypochlorite at a concentration of 20,000 ppm completely protected mice from prionosis. Further, in vitro assays suggest that potential proteolytic based PrPres decontamination methods must use high enzyme concentration, $\mathrm{pH}$ values $>9.0$, and elevated temperatures to be a safely efficacious, thereby limiting applicability on delicate surgical instruments and use in the environment.
\end{abstract}

Published by Elsevier B.V.

\section{Introduction}

Transmissible spongiform encephalopathies (TSEs) are progressive diseases for which aberrantly folded prion proteins (PrPres) appear to be the causative agent (Prusiner, 1982). The unique nature of PrPres, the many unanswered questions regarding TSEs, and the resistance of prions to decontamination, make containment of TSEs problematic. As there are no effective treatments for prion diseases, methods to decontaminate infected surfaces and sites are especially important for managing TSEs.

A variety of methods have been tested for prion destruction (Fichet et al., 2004; McDonnell and Burke, 2003). The prion decontamination methods currently suggested in The Biosafety in Microbiological and Biomedical Laboratories manual (USDHHS, 2007 ), such as high concentrations of hypochlorite or $1 \mathrm{~N} \mathrm{NaOH}$, are inconvenient because of noxious or irritating fumes and in many situations are not possible due to incompatibility with contaminated surfaces, materials, and equipment. Clearly, better methods for decontamination of PrPres are needed.

\footnotetext{
* Corresponding author. Tel.: +1 970266 6093; fax: +1 9702666157.

E-mail addresses: John.l.pilon@usda.gov (J.L. Pilon), Paul.b.nash@usda.gov (P.B. Nash), kurt.c.vercauteren@aphis.usda.gov (K.C. VerCauteren).

${ }^{1}$ These authors contributed equally to this work.
}

In spite of the resistance of PrPres to proteolytic inactivation, some proteolytic decontamination methods have been investigated with variable success. Protease digestion and elimination of ELISA or Western-blot immunoreactivity has been shown under a variety of conditions (Hui et al., 2004a, 2004b; Langeveld et al., 2003; Tsiroulnikov et al., 2004; Mitsuiki et al., 2006; Rapp et al., 2006; Scherbel et al., 2006; Muller-Hellwig et al., 2006). However, protease destruction of prions below in vitro assay detection limits does not necessarily mean that PrPres has been reduced to levels that are no longer infectious in more sensitive bioassays; therefore, methods investigating decontamination of infectious prions need to be tested in vivo until better in vitro methods are developed and validated (McLeod et al., 2004; Lawson et al., 2006).

Bioassays in live animals are more sensitive, test actual infection, are representative of natural infection, and can detect low-level residual infectivity that may reside below the limit of detection of traditional immunoassays. Experiments utilizing mouse bioassays to investigate decontamination of PrPres material with proteinase K (Jackson et al., 2005; Yakovleva et al., 2004), Properase (McLeod et al., 2004), and Rapid Multi-Enzyme cleaner $3 \mathrm{M}$ (Lawson et al., 2006), suggests that enzymatic approaches to PrPres contamination is achievable. Although the references cited were somewhat successful, the difficulty in achieving a robust PrPres decontamination method is also revealed in the published data.

The enzymatic digestion methods presented in this paper were used as an initial screen to test for economic feasibility, mild diges- 
Table 1

Conditions for treatment of mouse-adapted scrapie brain prior to injection into mice.

\begin{tabular}{|c|c|c|c|c|c|c|}
\hline Group & Prion & Treatment & Concentration & Time & Temp. & Inactivation \\
\hline Untreated & 1:100 RML & None & NA & NA & NA & No \\
\hline Negative control & Saline & None & NA & NA & NA & No \\
\hline Heated control & $1: 100 \mathrm{RML}$ & None & NA & NA & NA & Yes \\
\hline Subtilisin 309 high & $1: 100 \mathrm{RML}$ & Subtilisin 309 & $138 \mathrm{mAU} / \mathrm{ml}$ & $14 \mathrm{~h}$ & $55^{\circ} \mathrm{C}$ & Yes \\
\hline Subtilisin 309 med & $1: 100 \mathrm{RML}$ & Subtilisin 309 & $70 \mathrm{mAU} / \mathrm{ml}$ & $14 \mathrm{~h}$ & $20^{\circ} \mathrm{C}$ & Yes \\
\hline Subtilisin 309 low & $1: 100 \mathrm{RML}$ & Subtilisin 309 & $30 \mathrm{mAU} / \mathrm{ml}$ & $14 \mathrm{~h}$ & $20^{\circ} \mathrm{C}$ & Yes \\
\hline Subtilisin 309-v & $1: 100 \mathrm{RML}$ & Subtilisin 309-v & $138 \mathrm{mAU} / \mathrm{ml}$ & $14 \mathrm{~h}$ & $20^{\circ} \mathrm{C}$ & Yes \\
\hline Hypochlorite & $1: 100 \mathrm{RML}$ & Household bleach & $40 \%(v / v)$ & $1 \mathrm{~h}$ & $20^{\circ} \mathrm{C}$ & No \\
\hline Autoclave & 1:100 RML & Autoclave & NA & $20 \mathrm{~min}$ & $134^{\circ} \mathrm{C}$ & No \\
\hline
\end{tabular}

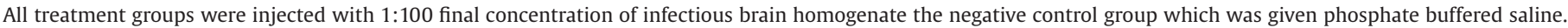
Heat inactivation was $85^{\circ} \mathrm{C}$ for $35 \mathrm{~min}$.

tion buffers, and readily achievable environmental conditions in reactions to proteolytically degrade PrPres . Therefore, subtilisin 309, manufactured under the commercial name Savinase (Novozymes, Bagsvaerd, Denmark), and subtilisin 309-v (Tindbaek et al., 2004), an engineered modification of subtilisin 309 to maintain high proteolytic activity at lower temperatures, were used at commercially economical enzyme concentrations, slightly basic digestion conditions and low temperatures. The conditions tested reveal that enzymatic degradation of PrPres will be difficult to achieve unless high; $\mathrm{pH}$, enzyme concentrations, and temperatures are used.

\section{Materials and methods}

\subsection{Enzymes}

Two enzymes: subtilisin 309 of Bacillus clausii (subtilisin 309), and a variant wherein valine at position 66 and serine at position 104 were substituted with alanine (subtilisin 309-v) to enhance proteolytic activity at lower temperature were used in this study to investigate enzymatic PrPres decontamination. Novozymes (Denmark) provided both enzymes. All enzyme units are reported as Anson units per $\mathrm{ml}(\mathrm{AU} / \mathrm{ml})$.

\subsection{ELISA and Western blot detection of PrPres}

To evaluate chronic wasting disease (CWD) enzyme digestion conditions mule deer (Odocoileus hemionus) brain (Colorado Division of Wildlife, Fort Collins, $\mathrm{CO}$ ) that had a predetermined PrPres concentration of $3 \mu \mathrm{g}$ PrPres/gram (Raymond et al., 2000) was used. Brain material was dounce homogenized at a 1:5 (w/v) concentration in water. Digestion reactions were carried out with $6.0 \times 10^{-5} \mu \mathrm{g}$ PrPres in $25 \mathrm{mM}$ Bicarbonate buffer at the indicated $\mathrm{pH}$ in a total volume of $100 \mu \mathrm{l}$ and incubated at $20^{\circ} \mathrm{C}$ for $14 \mathrm{~h}$. Enzyme was heat inactivated at $85^{\circ} \mathrm{C}$ for $35 \mathrm{~min}$. Untreated control was carried out in a parallel reaction in Delbecco's phosphate buffered saline. Evaluation of the remaining immunoreactive PrPres was evaluated at the Colorado State University Veterinary Diagnostic Laboratory using the BioRad procedure and BSE test kit (BioRad, Hercules, CA) under validated standard operating procedures approved by the USDA. All samples were run in triplicate wells. CWD brain homogenate used in Western blot samples were treated as described above except no subtilisin enzyme was added. After incubation and inactivation $20 \mu \mathrm{l}$ of samples were mixed with $5 \mu \mathrm{l} 5 \times$ gel loading buffer heat denatured and resolved on 4-20\% gradient SDS-PAGE gels (Invitrogen, CA). Resolved samples were transferred to polyvinylidene fluoride membrane (Millipore, Billerica, MA, USA). Membranes were blocked and with $5 \%(\mathrm{w} / \mathrm{v})$ powdered milk in TBST $(25 \mathrm{mM}$ Tris, $140 \mathrm{mM} \mathrm{NaCl}, 3 \mathrm{mM} \mathrm{KCl}$, 0.05\% Tween-20, pH 8.0). Primary antibody Bar 224 was added (SpiBio, Montigny-Le-Bretonneuxx-Cedex, France) at 1/2000 dilution in TBST and $1 \%$ milk for $2 \mathrm{~h}$ at room temperature. Blots were washed $3 \times 5 \mathrm{~min}$ and exposed to a $1 / 10,000$ dilution of secondary antibody (Antimouse HRP conjugated, Pierce, Rockford, IL, USA) for $1 \mathrm{~h}$. Blots were washed as above and samples were visualized by chemiluminescence (Super Signal, Pierce, Rockford, IL, USA) and photographed with a CCD camera.

\subsection{Digestion of material for in vivo mouse experiment}

Rocky Mountain Laboratory mouse-adapted scrapie strain was used (Rocky Mountain Laboratories, Hamilton, MT) for all in vivo testing. End-stage clinical positive brain was homogenized in PBS at $1: 10(w / v)$ using a hand held dounce. Homogenized brain material was further diluted in PBS to a final concentration of $1: 100$ $(\mathrm{w} / \mathrm{v})$. Treatment conditions used for decontamination are outlined in Table 1.

\subsection{Mouse inoculation and monitoring}

C57Bl/6 mice (Hilltop Laboratory Animals, Hilltop, PA) were injected with $50 \mu \mathrm{l}$ of treated or control brain homogenate in to the peritoneal cavity. The peritoneal route of challenge was chosen due to toxicity concerns of intracranial injections that could result from hypochlorite and residual enzyme matrix. Mice were monitored for kyphosis, ataxia, stiff tail, lack of grooming, emaciation, extreme lethargy/excitability; counting one point for each sign that was suspect, and two points for each distinct sign. When the condition of a mouse resulted in a score of $\geq 8$ points, or when a mouse had $\geq 6$ points for 3 days, the mouse was euthanized (hereafter referred to as death for simplicity). All animals were sacrificed at 18 months after challenge inoculation. All mouse experiments were conducted with the approval of the National Wildlife Research Center animal care committee and adherence to animal. welfare guidelines.

\subsection{Statistical analysis}

Survival analysis was performed on mouse survival data using the Log Rank test. Calculations were performed according to the British Medical Journal online survival analysis statistics instructions (eBMJ - Statistics at Square One: Survival analy-

Table 2

Survival of mice inoculated with treated mouse-adapted scrapie.

\begin{tabular}{lcclcc}
\hline Treatment Group & Total & Died & Range & Mean \pm S.D. & $P$-value \\
\hline Untreated & 5 & 5 & $213-213$ & $213 \pm 0$ & .33 \\
Saline control & 21 & 0 & - & - & $<.0001$ \\
Heated control & 21 & 20 & $220-262$ & $234 \pm 11$ & - \\
Subtilisin 309 $138 \mathrm{mAU} / \mathrm{ml}$ & 21 & 9 & $239-261$ & $248 \pm 8$ & $<.0001$ \\
Subtilisin 309 70 mAU/ml & 18 & 16 & $224-253$ & $233 \pm 8$ & .58 \\
Subtilisin 309 30 mAU/ml & 21 & 19 & $223-249$ & $233 \pm 8$ & .71 \\
Subtilisin 309-v $138 \mathrm{mAU} / \mathrm{ml}$ & 16 & 13 & $227-255$ & $241 \pm 9$ & .028 \\
Hypochlorite & 21 & 0 & - & - & $<.0001$ \\
Autoclave & 21 & 0 & - & - & $<.0001$ \\
\hline
\end{tabular}




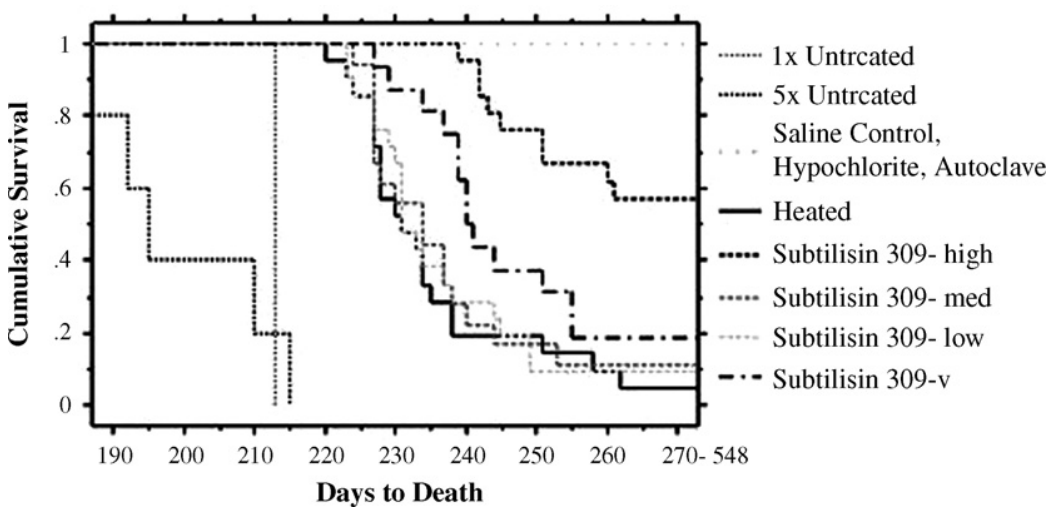

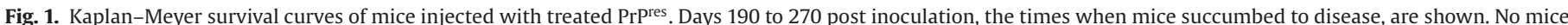
died of prion disease between 270 days and the 18 -month termination of the study.

sis [http://bmj.bmjjournals.com/statsbk/12.shtml]). Excel (version 2002; Microsoft Corporation) was used to obtain $P$-values from the chi-squared values and calculate standard errors on ELISA results.

\section{Results}

\subsection{In vivo testing of enzymatic destruction of PrPres}

The different treatment groups and the conditions for PrPres digestion used in the mouse bioassay are detailed in Table 1. All mice injected with untreated RML scrapie brain homogenate were dead by 215 days after inoculation, which is typical for a highinfectivity titer RML prion strain given intraperitoneally (Pilon et al., 2007). Table 2 presents the survival statistics. Surprisingly, the heat treatment used to inactivate the enzymes prior to injection led to a 21-day increase in mean survival time relative to the untreated control. Low $(30 \mathrm{mAU} / \mathrm{ml})$ and medium $(70 \mathrm{mAU} / \mathrm{ml})$ dose subtilisin 309 treatments did not statistically improve survival over heated control; although, an additional animal survived to the study endpoint for both the low and medium does subtilisin 309 treatment groups relative to the heated control. Treatment with subtilisin 309-v led to longer survival than heating alone with an increase in the mean time to sacrifice by 7 days, whilst an increase of $14 \%$ in survivorship was observed (Fig. 1). The most effective enzyme digestion condition $(P<0.0001)$ was subtilisin 309 at $138 \mathrm{mAU} / \mathrm{ml}, 55^{\circ} \mathrm{C}$, and $\mathrm{pH} 7.9$ with $14 \mathrm{~h}$ of treatment time. Treatment under these conditions reduced PrPres infectivity that eliminated disease in $57 \%$ of the mice, representing a $52 \%$ increase in survivorship compared to the heated control. Two recommended methods for PrPres decontamination, hypochlorite ( $40 \%$ bleach) treatment and autoclaving $\left(134^{\circ} \mathrm{C}, 20 \mathrm{~min}\right)$, eliminated all measurable PrPres infectivity in this bioassay and none of the mice in these groups died of prion disease by 18 months when the study was terminated.

\subsection{Digestion of PrPres (CWD) at alkaline $\mathrm{pH}$}

Since subtilisin enzymes are alkaline proteases and have increased activity at higher $\mathrm{pH}$, and the fact that PrPres decontamination procedures are needed to treat paddocks/environments to eliminate chronic wasting disease (CWD) PrPres infectivity, an in vitro ELISA assay was done to test the effect of $\mathrm{pH}$ and enzyme concentrations on PrPres digestion using CWD infected mule deer brain homogenate. As expected, $\mathrm{pH}$ has a very large influence on subtilisin activity and prion degradation as shown in Fig. 2. Absorbance readings were 4 -fold lower at $\mathrm{pH} 10.5$ compared to $\mathrm{pH} 8.2$ when the final concentration of enzyme activity was $0.6 \mathrm{mAU} / \mathrm{ml}$ for subtilisin 309. The strong $\mathrm{pH}$ dependence on digestion efficiency is reduced at higher enzyme concentration, with only a 2-fold and 1.5-fold reduction in ELISA absorbance observed between the high and low $\mathrm{pH}$ PrPres digestion reactions at 6.0 and $60 \mathrm{mAU} / \mathrm{ml}$ respectively. The performance of subtilisin 309-v was less effective across all $\mathrm{pH}$ values as shown in Fig. 2B. A reduction of immunoreactive signal and CWD prion degradation is expected due to $\mathrm{pH}$ effects alone. Therefore a Western blot was run to visualize the qualitative $\mathrm{pH}$ dependence on PrPres and is shown in Fig. 2C. The results show that $\mathrm{pH}$ alone reduces the immunoreactive signal by signifi-
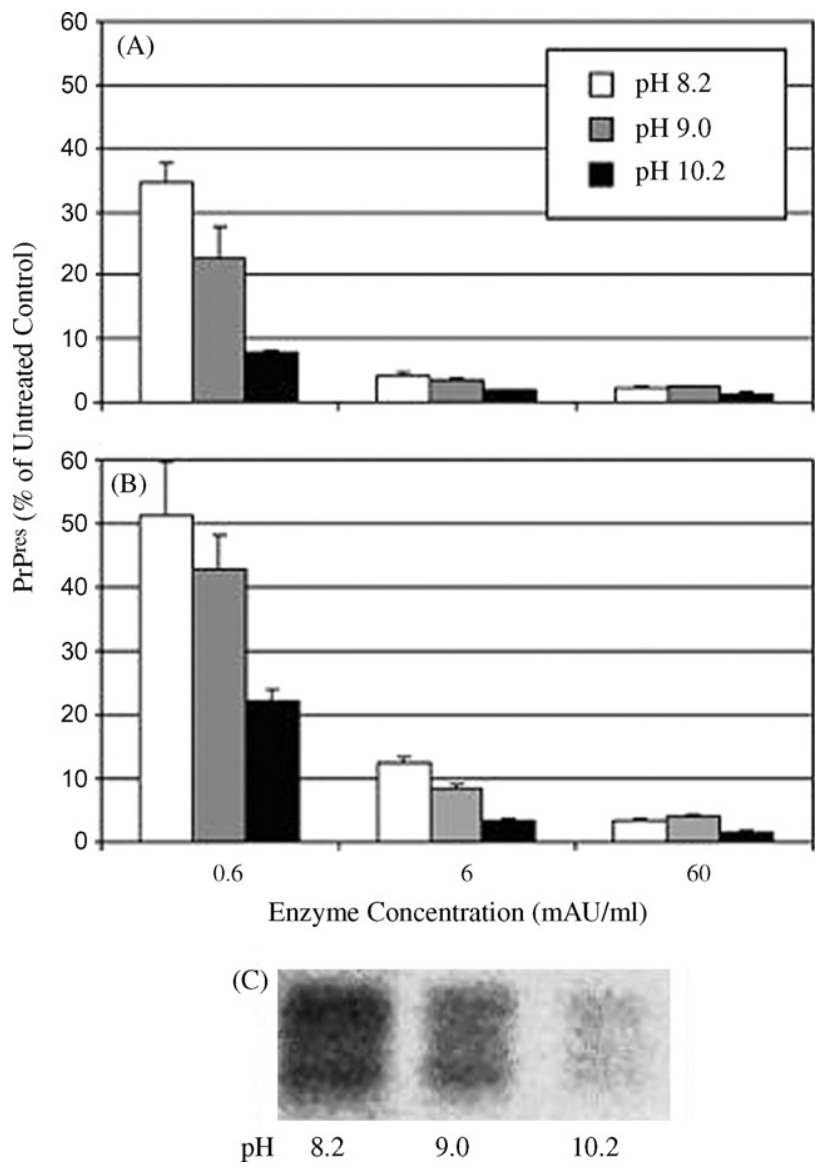

Fig. 2. (A) pH effects on subtilisin 309 and (B) subtilisin 309-vPrPres degrading activity measured by BioRad BSE ELISA and (C) Western blot pH dependence on immunoreactive signal. The results are expressed as percent of untreated positive brain due to the additive effects of increased $\mathrm{pH}$ on immunoreactivity and PrPres degradation. CWD positive mule deer brain was incubated at $20^{\circ} \mathrm{C}$ for $14 \mathrm{~h}$. All samples water treated at $85^{\circ} \mathrm{C}$ for $35 \mathrm{~min}$ prior to ELISA to inactive remaining enzymes. 
cant amounts. Densitometry measurements of Western blot signal showed a decrease of $30 \%$ and $60 \%$ at $\mathrm{pH}=9.0$ and 10.2 respectively relative to $\mathrm{pH}=8.2$.

\section{Discussion}

Our choice of bioassay conditions were largely defined by two considerations: (1) conditions had to be mild, for use on sensitive equipment or in environments where high $\mathrm{pH}$ may destroy microbes important for ecology; (2) enzyme concentrations needed to be held relatively low so decontamination methods could be applied economically by the end-user. To this end, even though PrPres digestion conditions for the bioassay were chosen based on loss of immunoreactivity in vitro (data not shown), no significant difference was observed in survivorship between subtilisin 309 PrPres digestions using 30 or $70 \mathrm{mAU} / \mathrm{ml}$ and the survivorship that was achieved by heating the homogenate to $85^{\circ} \mathrm{C}$ for $35 \mathrm{~min}$. Indeed, even the simple heating of PrPres increased survivorship by 18 days relative to the untreated control a result that was wholly unexpected. However, the delay in end-stage clinical symptoms is not without precedence, as a similar extension in life span upon heating of PrPres strains was observed by Taylor et al. (2002). The observed increase in lifespan was hypothesized to occur in the cited paper due to an alteration the structure PrPres strains that results in alternative processing routes by the body compared to unheated PrPres strains.

A statistically significant increase in survivorship was observed when enzyme concentration was increased and a higher digestion temperature was used. An infectious dose titration performed at Rocky Mountain Laboratories using the same prion strain and route of challenge in C57Bl/10 mice (Priola and Ward, personal communication) showed no deaths in mice inoculated with a $1: 10^{6}$ dilution of infectious brain material. Our high concentration subtilisin 309 treatment showed a higher percent survival than the $1: 10^{5}$ brain homogenate dilution point, indicating that our treatment was less than one log away from removal of infectivity as observed by clinical end-stage bioassay. Although it must be noted that the major histocompatibility complex difference in the congenic strains of mice may alter susceptibility to PrPres challenge, it is probable that the pattern of response to decreasing doses is similar.

In addition to mouse bioassay, digestions using a CWD PrPres strain with endpoint ELISA readout were conducted with $\mathrm{pH}$ and enzyme concentration as variables. The result of the in vitro assay showed the expected $\mathrm{pH}$ dependence on enzyme activity with increasing alkalinity. The observation that $\mathrm{pH}$ dependent dose response greatly decreases with increasing enzyme concentration suggests that a resistant core of PrPres infectivity may exist below the limit of quantitation (LOQ) of the ELISA assay, as raw absorbance is still slightly above background. As others have observed, in vitro results are not predictive of in vivo results (Jackson et al., 2005; Kocisko et al., 1995). Therefore, to conclude if the conditions used in our in vitro digestions conditions removed all detectable CWD PrPres infectivity, a bioassay using transgenic cervidized mice will be required. Of note is the fact that the observed decrease in PrPres dependent ELISA signal is additive with both enzyme concentration and increasing $\mathrm{pH}$ playing a critical role in decontamination reactions (Fig. 3). Western blot analysis of the effect of $\mathrm{pH}$ on PrPres quality and quantity did indicate significant alterations in PrPres levels.

The results presented herein reveal that enzymatic digestion at near neutral $\mathrm{pH}$, low activity, and moderate temperatures is not a viable option for PrPres decontamination. If optimum alkaline $\mathrm{pH}$, high enzyme concentrations and elevated temperatures are used, PrPres decontamination may be possible, although the broad-based practicality from an economic and operational standpoint would likely be limited. For enzymatic degradation of PrPres to be a use- ful tool, significant improvements are needed. For the particular enzymes used in this study, increasing $\mathrm{pH}$ may be a simple and effective improvement. Indeed, in vitro results show that increasing the $\mathrm{pH}$ of the digestion buffer as little as $1.0-1.5 \mathrm{pH}$ units can dramatically improve the enzymatic digestion of PrPres. In addition, additives such as detergents or chaotropic salts could also improve the enzymatic digestion of PrPres and allow for viable and economical PrPres decontamination method.

\section{Acknowledgments}

We thank Sue Priola and Anne Ward for providing the mouseadapted scrapie and the survival data on the infectious material dilutions, Terry Spraker and Mike Miller for providing CWD brain material, Kathi Wilson for running the BioRad ELISA, and Steffen Ernst and Garrett Screws from Novozymes for their support and advice.

Mention of companies or commercial products does not imply recommendation or endorsement. Product names are mentioned solely to report factually on available data and to provide specific information.

\section{References}

Fichet, G., Omoy, E., Duval, C., Antloga, K., Dehen, C., Charbonnier, A., McDonnel, G., Brown, P., Lasmezas, C.I., Deslys, J.-P., 2004. Novel methods for disinfection of prion-contaminated medical devices. Lancet 364, 521-526.

Hui, Z., Minamiguchi, K., Doi, H., Kinoshita, N., Kanouchi, H., Oka, T., 2004a. Recombinant alkaline serine protease II degrades scrapie isoform of prion protein. In vitro. Cell Dev. Biol. 40, 293-296.

Hui, Z., Doi, H., Kanouchi, H., Matsuura, Y., Mohri, S., nonomura, Y., Oka, T., 2004b. Alkaline serine protease produced by Streptomyces sp. degrades PrPsc. Biochem. Biophys. Res. Commun. 321, 45-50.

Jackson, G.S., McKintosh, E., Flechsig, E., Prodromidou, K., Hirsch, P., Linehan, J. Brandner, S., Clarke, A.R., Weissmann, C., Collinge, J., 2005. An enzyme-detergent method for effective prion decontamination of surgical steel. J. Gen. Virol. 86, 869-878.

Kocisko, D.A., Priola, S.A., Raymond, G.J., Chesebro, B., Lansbury Jr., P.T., Caughey, B. 1995. Species specificity in the cell-free conversion of prion protein to proteaseresistant forms: a model for the scrapie species barrier. Proc. Natl. Acad. Sci. U.S.A. 92, 3923-3927.

Langeveld, J.P.M., Wang, J.-J., Vande Wiel, D.F.M., Shih, G.C., Rarssen, G.J., Bossers, A., Shih, J.C.H., 2003. Enzymatic degradation of prion protein in brain stem from infected cattle and sheep. J. Infect. Dis. 188, 1782-1789.

Lawson, V.A., Stewart, J.D., Masters, C.L., 2006. Development of an enzymatic detergent treatment protocol that significantly reduces protease resistant prion protein load and infectivity from prion-contaminated surgical-steel monofilaments. Am. J. Infect. Control. 34, E29-E30.

McDonnell, G., Burke, P., 2003. The challenge of prion decontamination. Clin. Infect. Dis. 36, 1152-1154.

McLeod, A.H., Murdoch, H., Dickinson, J., Dennis, M.J., Hall, G.A., Buswell, C.M., Carr J., Taylor, D.M., Sutton, J.M., Raven, N.D.H., 2004. Proteolytic inactivation of the bovine spongiform encephalopathy agent. Biochem. Biophys. Res. Commun. 317, 1165-1170.

Mitsuiki, S., Hui, Z., Matsumoto, D., Sakai, M., Moriyama, Y., Furukawa, K., Kanouchi, H., Oka, T., 2006. Degradation of PrPsc by keratinolytic protease from Nocardiopsis sp. TOA-1. Biosci. Biotechnol. Biochem. 70, 1246-1248.

Muller-Hellwig, S., Groschup, M.H., Pichner, R., Gareis, M., Martlbauer, E., Scherer, S., Loessner, M.J., 2006. Biochemical evidence for the proteolytic degradation of infectious prion protein $\mathrm{PrP}^{\mathrm{sc}}$ in hamster brain homogenates by foodborne bacteria. Syst. Appl. Microbiol. 29, 165-171.

Pilon, J., Loiacono, C., Okeson, D., Lund. S., Vercauteren, K., Rhyan, J., Miller, L., 2007. Anti-prion activity generated by a novel vaccine formulation. Neurosci. Lett. 429, $162-164$.

Prusiner, S.B., 1982. Novel proteinaceous infectious particles cause scrapie. Science 216, 136-144.

Rapp, D., Potier, P., Jocteur-Monrozier, L., Richaume, A., 2006. Prion degradation in soil: possible role of microbial enzymes stimulated by the decomposition of buried carcasses. Environ. Sci. Technol. 40, 6324-6329.

Raymond, G.J., Bossers, A., Raymond, L.D., O'Rourke, K.I., McHolland, L.E., Bryant III, P.K., Miller, M.W., Williams, E.S., Smits, M., Caughey, B., 2000. Evidence of a molecular barrier limiting susceptibility of humans, cattle and sheep to chronic wasting disease. EMBO 19, 4425-4430.

Scherbel, C., Pichner, R., Groschup, M.H., Mueller-Hellwig, S., Scherer, S., Dietrich, R., Maertlbauer, E., Gareis, M., 2006. Degradation of scrapie associated prion protein $\left(\mathrm{PrP}^{\mathrm{sc}}\right)$ by the gastrointestinal microbiota of cattle. Vet. Res. 37, 695-703.

Taylor, D.M., Fernie, K., Steele, P.J., McConnell, I., Somerville, R.A., 2002. Thermostability of mouse-passaged BSE and scrapie is independent of host PrP genotype: implications for the nature of the causal agents. J. Gen. Virol. 83, 3199-3204. 
Tindbaek, N., Svendsen, A., Oestergaard, P.R., Draborg, H., 2004. Engineering a substrate-specific cold-adapted subtilisin. Protein Eng. Des. Sel. 2, 149-156.

Tsiroulnikov, K., Rezai, H., Bonch-Osmolovskaya, E., Nedkov, P., Gousterov, A., Cueff, V., Godfroy, A., Barbier, G., Metro, F., Chobert, J.M., Clayette, P., Dormaont, D. Grosclaude, J., Haertle, T., 2004. Hydrolysis of the amyloid prion protein and nonpathogenic met and bone meal by anaerobic thermophilic prokaryotes and Streptomyces subspecies. J. Agric. Food Chem. 52, 6353-6360.
U.S. Department of Health and Human Services, 2007. Biosafety in Microbiologica and Biomedical Laboratories. U.S. Government Printing Office, Washington, DC. Yakovleva, O., Janiak, A., McKenzie, C., McShane, L., Brown, P., Cervenakova, L., 2004. Effect of protease treatment on plasma infectivity in variant Crutzfeldt-Jakob disease mice. Transfusion 44, 1700-1705. 